\title{
Coriolanus: Celebrating a Bakhtinian Anarchic Body of Roman Republic
}

\author{
Roohollah Datli Beigi ${ }^{a}$, Pyeaam Abbasi ${ }^{\mathrm{b}}$ \\ Department of English, Faculty of Foreign Languages, University of Isfahan, Isfahan, Iran \\ ${ }^{a, b}$ E-mail address: rohollah85datlibeigi@yahoo.com ,Pyeaam77@yahoo.co.uk
}

\begin{abstract}
The last tragedy of Shakespeare, Coriolanus (1608), is one of the most ignored and controversial Shakespearian plays towards which there has always been a sort of dislike. Despite the fact that the dislike is attributed by many critics to the play's harshness, it can be analyzed in terms of the play's protagonist and the low language he uses. Cursing language is the most important feature of Coriolanus which undermines him into a grotesque figure, removes the audience's and the reader's sympathy with him, and questions the authoritative language of the play. This study uses Mikhail Bakhtin's ideas to bring under scrutiny Shakespeare's unpopular protagonist in terms of his cursing and obscene language or voice. Using such ideas as "heteroglossia," "grotesque body" and "carnival" it will be argued that Shakespeare through language makes the audiences sympathize neither with patricians nor plebeians, but gets them to stand and criticize a contemporary issue. This so-called "alienation effect" created by Shakespeare changes the play into an epic theatre. Also, it is shown that "heteroglossia" and the grotesque quality of Coriolanus' language help to undermine the authoritative or "unitary language" of the play as a systematic whole. In other words, the stable society and language Shakespeare is after are subverted by the heteroglot and grotesque language of Coriolanus and Menenius.
\end{abstract}

Keywords: Coriolanus; Mikhail Bakhtin; heteroglossia; grotesque; carnival; alienation effect

\section{INTRODUCTION}

The Tragedy of Coriolanus (1608), written at the end of Shakespeare's literary career, is one of the most ignored and controversial Shakespearean plays towards which there has always been a sort of dislike. The story of the play has been briefly described by Livy and then comprehensively by Plutarch in his Lives of the Noble Grecians and Romans. The dramatized version by Shakespeare describes, half-legendarily, the dawn of the Roman republic; unlike Antony and Cleopatra and Julius Caesar that set in the last days of this Empire. In this history play, the history of a Rome is depicted that is segmented very sharply into "plebeians" and "patricians." Coriolanus has been admired by many literary figures, Coleridge, Swinburne and Brecht among them. The play has been recently interpreted to be an "interpretation of post-modernist deconstruction" (Parker 1998, 1-2). Brian Vickers, in his Shakespeare: Coriolanus, argues that the play is "Shakespeare's most complex play," (1976, 7) and in terms of poetic aspects of the play, T. S. Eliot claims that Coriolanus, along with Antony and Cleopatra, is "Shakespeare's most artistic success" (1932, 144). However, most 
Shakespeare's readers and audiences have been, as Jan Kott argues, "discouraged, revolted, or - at least - unmoved by it" (1967, 141). Kott calls the play "one of Shakespeare's most profound works," but explains that the dislike felt for the play for so long has been partly due to the play's "austerity of dramatic matter" since the play, according to him, is "harsh and austere" (142). Similarly, Maurice Hunt has claimed that Coriolanus, alongside Titus Andronicus and Timon of Athens, is "one of Shakespeare's least popular tragic protagonists" and argues that Shakespeare in his late tragedy has depicted Coriolanus as "the early modern equivalent of an antihero" (2004, 229).

Despite the fact that the play's being disliked and unpopularity is, to some extent, explainable in terms of its harshness, the reason of this dislike - at least some part of it - is the play's protagonist and the low language he uses. Willard Farnham attributes the dislike and Coriolanus' flaw to his pride and makes the point that Shakespeare's hero is "a proud man" that "whenever we see his wrath, we know that it is fed by pride." Farnham continues that pride in Coriolanus is "a spiritual flaw reaching to the depth of his being" $(1965,135)$. In terms of speech and the power of language, Paul A. Jorgensen compares Shakespeare's Coriolanus with Plutarch's and argues that unlike Shakespeare's, Coriolanus in Plutarch is presented as "a clever and eloquent, though not a wise or disciplined character." Plutarch's Coriolanus is a craftsman in war and "conspicuously an orator," while Shakespeare's protagonist "vividly demonstrates [...] his limited ability in speech" $(1965,123)$. Jorgensen states that Coriolanus' failure in "public affairs" or his tragedy is in part due to his "lack of appropriate words" (125) and inability to speak but does not refer to his cursing and insulting language.

According to the Renaissance conventions, such noble characters as Coriolanus had to speak in a high verse language, while the lower and marginal characters spoke in prose; however, this hierarchy is overlooked by Shakespeare. In his first appearance, Coriolanus' high language is interspersed with a low language of curse and insult that resembles Caliban's. According to Hunt, these two characters' voices are identical, since Caliban uses a "cursing voice" and the same "cursing voice is likewise coming from Coriolanus" (226) while, the former is a slave and the latter is a noble Roman warrior. Addressing the plebeians, Coriolanus reviles the rebellious citizens:

What's the matter, you dissentious rogues, That, rubbing the poor itch of your opinions Make yourselves scabs?

What would you have, you curs,

That like nor peace nor war? The one affrights you,

The other makes you proud. He that trusts to you,

Where he should find you lions, finds you hares;

Where foxes, geese: you are no surer, no,

Than is the coal of fire upon the ice,

Or hailstone in the sun. (I. i. 161-71)

In this play, Shakespeare introduces a Rome in which an ongoing struggle between the poor and the rich is observable. Class distinction is even apparent and confirmed by the war, since "plebeians and patricians behave differently in war" (Kott 1967, 154); while patricians take part bravely in battle, plebeians escape from the war snatching from each other the war spoils. In the battle field they seem more "ready to run or loot than to fight" (Hunt 2004, 232). At the very beginning of the play plebeians are struggling over the scarcity and price of the 
grain in order to "have corn at [their] own price" (I. i. 10). From this very beginning a revolution is introduced as the first scene opens with the mutinous, angry plebeians who enter, while, shouting and demanding a reduction of the grain price. Also, the central idea of class conflict between plebeians and patricians is introduced at this outset: "we are accounted poor citizens, the patricians good" (I. i. 14-15). In other words, the play opens with a Bakhtinian carnival, because plebeians have revolted against patricians and as Michael Holquist declares "Bakhtin's carnival [...] is revolution itself" (1977, xviii). Similarly, according to Booker, Bakhtin's carnival undermines hierarchies and thus "provides a metaphor for political revolution" $(1996,107)$. Class struggle between the rich and the poor is considered to be a Bakhtinian discourse too.

Through using such Bakhtinian concepts as "carnival," "grotesque body" and "dialogism" this study is going to bring under scrutiny the language of the play to show that Shakespeare, by means of language, has been making the audience sympathize with neither patricians nor plebeians; instead, he attempts to draw their attention to a contemporary political or social issue. This so called Brechtian "alienation effect" occurs, to some extent, by the grotesque language or the language associated to the "grotesque image of the body." In other words, Aristotelian "either-or" logic which demands a final given conclusion of the text is rejected, for, there is a kind of ambivalence in the play that refuses "simple choices between opposing alternatives" (Booker 1996, 105). Also, using the ideas of "unitary language" and "heteroglossia" coined and expounded by the Russian formalist critic, Mikhail Bakhtin, it will be shown that the language of the play is not simply a "unitary language" or a unified and centralized system with "centripetal" tendencies, but rather a "double-accented, double-styled hybrid construction" (Bakhtin 1981, 304). In Coriolanus, not only there is an interaction between high languages and low, but also the language used by such characters as Coriolanus or Menenius Agrippa is not pure as it is amalgamated with others' words or other kinds of languages.

\section{DISCUSSION}

Character and imagery are two important aspects of Shakespeare's plays. Characterizing his protagonists through different images has been a frequent technique used by Shakespeare in his plays. By means of imagery he describes his great heroes such as Othello, Macbeth and Caesar and makes them larger than life and distinguishable from the marginal characters. The function of imagery in Shakespeare, as Clemen argues, is generally to clarify the main theme of the play. This function, particularly in Coriolanus, is both significant and interesting, for in this play, like other Shakespearean plays, imagery "throws much light on Shakespeare's attitude towards a general problem" (Clemen 1951, 154).

Although, Shakespeare's opinions and what he thinks about his characters are not explicitly mentioned in his passages, his attitudes towards certain problems and characters are subtly implied, and imagery is the most effective device he uses for this purpose. In Titus Andronicus and other early plays of Shakespeare, imagery is used abundantly and exaggeratedly. In these early plays, there is "a tendency to spin out, expand and elaborate images" (220).

On the contrary, in his later plays images are more suggestive, dramatic and implicit. Coriolanus, though a late tragedy, is an exception in using "lavish and outspoken" images (228). As Clemen points out, unlike Macbeth and Antony and Cleopatra, imagery in Coriolanus is "less intricate and complex" (154). There is nothing ambiguous about the play's 
protagonist; in contrast to Hamlet who is "never identical with himself," Coriolanus is "exactly what he is, and so a sort of blank tautology" (Eagleton 1986, 73).

Animal imagery is frequently used throughout the play. In contrast with the plebeians who are described by such humble and timid animals as dogs, cats, curs and rats: "take these rats thither / to gnaw their garners" (I. i. 256-7), brave animals like dragon, eagle and tiger are used to characterize Coriolanus' heroic actions who "fights dragon-like, / and does achieve as soon as draw his sword" (IV. vii. 23-24). However, considering his low curse language, images related to the lower part of the body and bodily functions are employed to depict those grotesque aspects of his nature that help to rank him among the most unpopular Shakespearean tragic protagonists and create a distance between him and the audience or the reader. In this regard, corn imagery and more significantly Bakhtinian "grotesque image of the body" become important, since, among other images, they are frequently used by Shakespeare to embody Coriolanus unequivocally; particularly those characteristics associated with his low language of insult, curse and scorn.

The grotesque body refers to Rabelais's paying attention to those aspects of human life such as "eating, drinking, defecation and sexual life" that emphasize physical aspects of human beings as they are related to the "material bodily lower stratum" (Bakhtin 1984, 332). According to Bakhtin, the grotesque body is "a body in the act of becoming. It is never finished, never completed;" in the grotesque image of the body, the leading role is given to "the bowels and the phallus" and next to these areas stand "the mouth" and "the anus" (316). However, in "the canon of polite speech" established at the end of the sixteenth and early seventeenth century - precisely the period when most Shakespeare's play were written - the leading role was attributed to "the head, face, eyes, lips" and other expressive parts of the body (319-20). Hence, the excremental and sexual functions, related to the lower parts of the body such as "the genital organs, the anus and buttocks, [and] the belly" were denied (318). It is worth emphasizing that these lower parts were not entirely eliminated from the literary images, but whenever emerged, they fulfilled "the functions of characterization and individualization" (319). To be precise, they did not have any symbolic meaning in this polite canon. The crucial point here is that these rules and conventions of the time are overlooked in Coriolanus.

Bakhtin singles out the "grotesque body" from the "classical body;" whereas, according to Bakhtin, the classical body and art is a perfect, "finished and completed" achievement, "the grotesque body of Rabelais and the kind of art which he represents appears unfinished." In the grotesque body, "becoming rather than completion is evident;" in such a body "the orifices [are] evident through which it sucks in and expels the world" (Dentith 2005, 65-66). In classical art and literature the body was divided into the high and low parts and thus no attention was paid to the lower parts because of their association with defecation and sexuality. In this regard, Bakhtin makes the point that "traditional attempts to taxonomize the body into high and low segments stand as a figure for the oppression of marginal social groups by dominant ones in class society" (qtd. in Booker 1996, 107). Accordingly, traditional classification of both bodily segments and literary genres into high and low justifies domination of the ruling class over the marginal oppressed ones. As Stallybrass and White observe:

The ranking of literary genres or authors in a hierarchy analogous to social class is a particularly clear example of a much broader and more complex cultural process whereby the human body, psychic forms, geographical space, and the social formation are all constructed within interrelating and dependent hierarchies of high and low. $(1986,2)$ 
As many critics have unanimously suggested, the last two syllables in Coriolanus' name (anus) refers to that part of the body associated with the bodily function of defecation. Moreover, this late tragedy of Shakespeare seems to acknowledge what Brown calls "the ongoing process of life" $(2001,363)$, that shows the play's unfinished, unfinalized and carnivalesque quality. Maurice Hunt asserts that the protagonist of this Shakespearean tragedy is "nominally associated with the anus" $(2004,221)$, that means, he is related to the lower part of the body and bodily functions which were denied in Shakespeare's era. Considering the hierarchical ranking of literary genres and its analogy with bodily segments, Coriolanus' being associated with lower parts can be taken as a perspicuous carnivalesque gesture or the grotesque image of the body by which the physical aspects of human life - here excrement are emphasized. In other words, a "carnivalesque representation of body functions" is rendered that means, unlike the classical body, there is a dialogic interaction between the body and the world by "the transfer of physical material from the interior of the body into the outside world and vice versa" (Booker 1996, 107). Likewise, Coriolanus' refusal to use a somber and tragic language, which he, as a distinguished tragic hero, is supposed to use, and the Calibanian curse language he uses instead, is not only the rejection of the "unitary" or authoritative language but also can be seen as a carnivalesque violation of literary hierarchies as well. Such grotesque images are apparently in contrast with official language, classical body and the idea of decorum which have been dominant in the Renaissance period and the canon of polite speech. Coriolanus, according to the traditional view, belongs to patricians who are associated with high segments of the body. However, by violating traditional hierarchies Shakespeare makes him identical with lower parts of the body; an idea in accord with Bakhtin's discussion of Rabelais' undermining "the usual hierarchical privileging of the high parts of the body over the low" (Booker 1996, 107).

In a similar way, a grotesque image of the body is presented in Menenius' "belly fable" in which "the belly" and body functions - belch and passed wind - forbidden by "the canon of polite speech" are given the leading role. His fable is grotesque because as R. B. Parker in his introduction to the play argues, one recurrent error concerning Menenius and his fable is to take it "too seriously and then to assume that they represent Shakespeare's own opinion" $(1998,44)$. Although Menenius is a patrician, Shakespeare renders a grotesque image of him by giving him a role "similar to that played in Hamlet by Polonius" (Kott 1967, 150). In Menenius Agrippa's fable, the belly stands for the Roman senates and the body's rebellious parts for plebeians: "The senators of Rome are this belly / And you the mutinous members" (I. i. 145-6). However, according to the Renaissance hierarchy, the state was simulated to the body in which the king or the blue-blooded were the head and other members of the society, based on their position, the other organs. As aforesaid, at the end of the sixteenth and early seventeenth century in literary images the leading roles would be attributed to the head, heart, eyes and other expressive parts of the body that is reflected in the first citizen's words:

The kingly crowned head, the vigilant eye,
The counselor heart, the arm our soldier,
Our steed the leg, the tongue our trumpeter,
With other muniments and petty helps
In this our fabric, if that they - (I. i. 112-16)

In Menenius' fable, unlike the first citizen's words, there is no place for the head; "just members, and the smiling sovereign belching belly" (Parker 1998, 45). Menenius Agrippa in his fable of the belly and in order to reply the first citizen's question: "well, sir, what answer 
made the belly?" (I. i. 103), employs, in Hunt's words, an "insulting audible body language" (2004, 222). He says:

Sir, I shall tell you, with a kind of smile, Which, ne'er came from the lunge, but even thus For, look you, I may make the belly smile As well as speak - it tauntingly replied To th' discontented members, the mutinous parts That envied his receipt; even so most fitly

As you malign our senators for that They are not such as you. (I. i. 104-11)

As the case was in Coriolanus' language, Menenius' transgressive speech also is grotesque in this way that, he not only spurns the authoritative language by re-accentuating another's speech - the belly fable that is a current opinion - but also ignores conventional hierarchies by identifying the Roman senates with the belly. Furthermore, in his fable, the belly's answer to "the mutinous parts" of the body refers to "either a willed belch or report of passed wind" that is, indeed, the patricians' insulting or "contemptuous reply to commoners" (222). The point is that, although Menenius speaks in an elevated verse language marked by reason and calmness, as well as distinguished from the angry and sometimes violent language used be the plebs, when he addresses the commonality, layers of offence and ugliness are hidden in his speech and the belly's answer; while, in his addressing Coriolanus and other Roman senates he uses a more lofty and courteous language. Likewise is Coriolanus' speech: while he employs a very harsh language for the plebs and the Roman soldiers as "All the contagion of the south light on you / You shames of Rome!" (I. v. 1-2), he speaks to his wife very softly. After his remarkable triumph over the Corioli, when Coriolanus returns home and finds his wife weeping, he uses a language that, in contrast to his language in addressing the mob, is too soft and sensitive. He cries:

My gracious silence, hail!

Wouldst thou have laughed had I come coffined home,

That weep'st to see me triumph? Ah, my dear,

Such eyes the widows in Corioli wear

And mothers that lack sons. (II. i. 170-4)

And surprisingly the only other person Coriolanus addresses in this way is Valeria:

The noble sister of Publicola,

The moon of Rome, chaste as the icicle

That's curdied by the frost from purest snow

And hangs on Dian's temple - dear Valeria! (V. iii. 64-67)

In fact throughout the play different sorts of languages are employed by Coriolanus in different situations. One moment his language is offensive, the next moment it is obscene; his language at home and in speaking with his wife is over-sensitive and sentimental, while fighting in the battle field it is war-like, powerful and even persuasive; in fighting Volscians he asks his generals to "put your shields before your hearts, and fight / With hearts more proof than shields" (I. i. 24-25). This multiplicity of languages shows the unfinalizability and nonfixity of both language and Coriolanus' essentially multi-faced character and brings under question the unity of the play's text as a systematic whole. Likewise, it provides further 
insight into Bakhtin's conception of "heteroglossia" which indicates every person, willy-nilly "live[s] in several language systems," and thus the languages he uses in different occasions vary automatically. Similarly, Menenius' fable of the belly is heteroglot since, to use Bakhtin's words, it is "another speech in another language, serving to express authorial intentions but in a retracted way" $(1981,295)$.

In this regard, another Bakhtinian idea related to Menenius' belly fable is the concept of "re-accentuation." Bakhtin, in Speech Genres and Other Late Essays, suggests that "our speech, that is, all our utterance, is filled with others' words, varying degrees of otherness or varying degrees of our-own-ness," and then continues that "these words of others carry with them their own expression, their own evaluative tone, which we [...] re-accentuate" (1986, 89). "Re-accentuation" is a process "through which speakers and writers repeat the words of previous speakers and writers but modify the meaning and orientation of those words by adding their own intonation" (Booker 1996, 269). It means that the current speakers or writers, by using others' words, express their own intentions or use those opinions to serve their own purposes. Therefore, the fable of the belly is, in fact, "another's speech," not a literal belly's but a symbolic one's; the anecdote and the belly's answer refer to what Bakhtin calls "the speech of current opinion" $(1981,305)$. It is, to use Menenius' words, "a pretty tale. It may be you have heard it / but since it serves my purpose [authors' emphasis], I will venture / to state't a little more" (I. i. 67-9). The fable is "completely at the level of common opinion," (Bakhtin 1981, 306) that is, it must have been heard, in one way or another, by the Roman citizens. In other words, it is not Menenius' own words, but an impersonal general opinion by means of which he paves the way to serve his intention or purpose, that is, to persuade the citizens to leave up their mutiny and accept the current situation.

Up to this point, the study showed that the grotesque image of the body, attributed to such characters as Coriolanus and Menenius and associated to their language, undermines the unitary or authoritative language of these characters and the author as well as the unity of the play as a whole. From now on, it will be discussed that Shakespeare, on the one hand, through "parad[ing] ugliness" (Meyerhold 1969, 137-8) into the speech of his noble characters and, on the other hand, by using "degradation," particularly in the part of plebeians, who are described by such humble epithets as timid animals, makes the audience sympathize with neither patricians nor plebeians. Although in some parts of the play it seems that Shakespeare sympathizes with his desperate mob, they are depicted as "irrational, unstable, savage, and at the mercy of every whim and demagogue," (Parker 1998, 46) that seals Shakespeare's abhorrence of and the audience's lack of sympathy for them. Instead, he seems has intended to, via creating the so-called "alienation effect," make the audience or reader stand against and criticize a contemporary political or social issue, which is the corn price and scarcity Britain encountered in 1600s.

Bakhtin's idea of "carnivalesque" or "carnival grotesque" as Maarten Van Dijk points out, is considered to be "a promising strategy for countering such fixed and impermeable hierarchies, especially in connection with Shakespeare" (2001, 165). As Bakhtin declares in Rabelais and His World, the carnivalesque form function is to consecrate freedom, to permit the combination of a variety of different elements and their rapprochement, to liberate from the prevailing point of view of the world, from conventions and established truth, from clichés, from all that is humdrum and universally accepted. This carnival spirit offers the chance $[\ldots]$ to enter a completely new order of things. $(1984,34)$

One of these mentioned hierarchies and established truths rejected by Bakhtinian discourse is "the either-or logic of the Aristotelian tradition" which demands, among other things, "coming to final conclusion" and regards conventional decorum. In other words, this 
new order, Bakhtin speaks about, has an ambivalent quality that is the essence of carnivalesque imagery. This ambivalence means that "different viewpoints, different worlds, may be mutually and simultaneously present without any privileging of one over the other" (Booker 1996, 109). It refers to Bakhtin's well-known dictum in his works that "no human experience is ever totally completed and that there can never be a 'last word' on any topic" (274).

With regard to the idea of ambivalence, as well as Brecht's concepts of "epic theatre" and its contrast with Aristotelian tradition of dramatic theatre, Meyerhold argues that "the grotesque does not recognize the purely debased or the purely exalted. The grotesque mixes opposites," and more tellingly, "the grotesque parades ugliness in order to prevent beauty from lapsing into sentimentality" (1969, 137-8). In other words, the function of the grotesque is precisely similar to Brecht's epic theatre in which, as Walter Benjamin asserts, an "abyss" there appears that "separates the actors from the audience like the dead from the living, the abyss whose silence heightens the sublime in drama" (Benjamin 1998, 1). In such a theatre, Brecht believes, "the audience's capacity for action must be roused and, far from undergoing catharsis, it must be forced to take decision, partly by its standard expectations being disappointed" (Habib 2005, 542). This process by which the audience or reader is separated from the actors or characters is called, by Brecht, the "alienation effect." In contrast, in Aristotelian dramatic theatre, a "relief or catharsis for various emotions, primarily pity and fear" (Habib 2005, 55) is provided that in turn requires the audience's identification and sympathy with the characters.

Similarly, in Coriolanus it is the grotesque that through parading ugliness, curse and offence into Coriolanus' language metamorphoses him into an antihero who, to use Kott's words, "can rouse all sorts of emotions, but never sympathy" (1967, 141). Cursing is a noticeable feature in Coriolanus' language that even sometimes his cursing voice is explicitly mentioned by Shakespeare in directions: "Enter Martius, cursing" (I. v). Shakespeare's unpopular protagonist, like Caliban in The Tempest, has "a cursing excremental voice and a less frequent, more melodic, poetic one" (Hunt 2004, 229). As Hunt explains, two distinctive voices are identified in Caliban: "a cursing voice and a more refined poetic one." Hunt argues that "the first voice is that of Prospero's slave" (2004, 225). As Prospero's slave, he uses a very offensive cursing voice or language: "a south-west blow on ye / and blister you all o'er" (The Tempest I. ii. 324-25). He never answers his master respectfully. Addressing Prospero and Miranda, he cries naughtily:

You taught me language and my profit on't

Is I know how to curse:

The red plague rid you

For learning me your language! (I. ii. 364-67)

Comparable to Coriolanus' voice, Caliban's also is so insulting and nasty that according to Hunt "usually work[s] against playgoers' inclination to pity the enslaved creature" (2004, 226). The same process occurs for Menenius Agrippa, who as a patrician can never invite the audiences' identification and if anything he spurns their sympathy which is mainly because the language he uses in his rendering of the belly fable is spoiled by a sort of hidden ugliness. In a similar way, Coriolanus' low language of curse, insult and scorn, smashes the image of him as a noble hero that "Roman commoners and theatre audiences struggle to form" (Hunt 2004, 227). In other words, the audience has sympathy neither with Caliban nor Coriolanus, and this is partly because ugliness is entered into their language and consequently the audience or reader's "standard expectations" regarding these characters, especially the latter, 
are disappointed (Habib 2005, 542). Hence, the grotesque, in Coriolanus, functions very much akin to Brecht's alienation effect: "it renders the familiar strange and requires the audience to have a critical attitude" (Van Dijk 2001, 169). This critical attitude in the play is directed, in one way or another, towards the corn issue emphasized by Shakespeare. Shakespeare's emphasis on this contemporary issue reflects events of early seventeenth century in England during which London encountered a dearth of corn and thus rioters forced the shopkeepers to sell food at their price: "let us kill [Coriolanus], and we'll have corn at our own price" (I. i. 10-11). At this period, as Parker explains, England was faced with "a time of exceptionally bad harvests and soaring food price" $(1998,34)$ that is reflected in Coriolanus and in the struggle between plebeians and patricians.

Another related Bakhtinian aesthetic idea observable in Shakespeare which makes the audience sympathize with neither Coriolanus nor the plebeians, is the idea of "degradation." This concept, as the most important property of the "grotesque realism," is in fact "the lowering of all that is high, spiritual, abstracted" (Bakhtin 1984, 19). According to Bakhtin, in the writings of such high-culture figures as Rabelais and Shakespeare, "the high, the elevated, the official, even the sacred, is degraded and debased" (Dentith 2005, 66). Thus Shakespeare, by entering curse and ugliness into Coriolanus' language on the one hand and, employing humble names for the plebs on the other, repudiates any sympathy for them.

Carol Sicherman opens her article with the argument that "Coriolanus and Cordelia have one trait: both reject formal public utterance" $(1972,189)$. Coriolanus' language does not follow the conventions of his time, and his tragedy is partly because "he is forever seeking a level of intention deeper [...] than that stipulated by the public conventions of language" (qtd. in Parker 1998, 83). In Coriolanus' speech there is a "disjunction between heart and brain," that is between passion and reason (Sicherman 197). His speech undoubtedly - at least most of it - emanates through his passion rather than his reason and thus provides him with "flows of pride, irascibility, and unsociability" (Langis 2010, 3). Sicherman makes the point that Coriolanus "never learns to speak his feelings with precision" $(1972,189)$ which is mainly because, instead of reason, the source of his speech is his passion. In this regard, Hunt avers that as a Roman noble warrior Coriolanus seems "to lack an inner censor, the primitive equivalent of the Freudian superego that represses and regulates the expression of id-like passions and urgings" $(2004,233)$. To be more exact, his speech is a mixture of reason and passion. In Menenius' words:

$[\mathrm{H}] \mathrm{e}$ has been bred i' th' wars

Since a' could draw a sword, and is ill schooled

In bolted language; meal [reason] and bran [passion]

together

He throws without distinction. (III. i. 323-26)

This suggests that the gracious and poetic part of his speech is spoiled or debased by his passion and he cannot eliminate it from his language in order to have a pure, reasonable and soft one. Related with the recurring corn imagery of the play, "meal and bran" refer to different aspects of Coriolanus' language. "Meal" refers to the poetic and sensitive aspect of his voice that is used very scarcely throughout the play, since he denies a "kindly relationship to all but a chosen few" (Parker 1998, 83). In contrast, "bran" stands for his frequently used cursing language that degrades him into a non-pitiable tragic hero who, according to Eagleton, "though literally a patrician, is perhaps Shakespeare's most developed study of a bourgeois individualist" $(1986,73)$ and according to Hunt "the early modern equivalent of an antihero" (2004, 229). 
Likewise, Shakespeare degrades his Roman commonality in order to avert the audience's sympathy for them. Although they are not such elevated and noble people to be degraded and debased, Shakespeare at the beginning of the play depicts them in such a way that arouses anybody's sympathy and pity, and then removes this sense of sympathy by using humble epithets for them: cats, dogs, rates, geese and curs are a few to count that are described as terms of contempt. Lines 120 through 124 of scene 3 of the $3^{\text {rd }}$ act read:

You common cry of curs, whose breath I hate

As reek o' th' rotten fens, whose loves I prize

As the dead carcasses of unburied men

That do corrupt my air - I banish you.

Concurrent with the seventeenth century corn issue mentioned earlier, there appeared a sort of conflict between the peasants and local gentry that was suppressed by the gentry. Because Shakespeare himself was a landowner at that time, it has been mentioned by many critics that he naturally must have been for the gentry and therefore for patricians in Coriolanus. However, Parker argues that there is no reliable evidence to show Shakespeare's being for the gentry and "if anything [it] suggests opposition to enclosure rather than support of it". This suggests that Shakespeare in Coriolanus has a "sympathetic representation of the Roman populace," $(1998,36)$ that is reflected in the first citizen's cry: "the gods know I speak this in hunger for bread, not in thirst for revenge" (I. i. 22-23). In spite of this apparent sympathy he shows for the Roman citizens, it cannot be said decidedly that Shakespeare intended to seek the audience's sympathy for plebeians. In contrast, his using of "depreciatory names for the rabble" (Clemen 1951, 228) and depicting them as irrational and savage creatures pave the way for the audience and readers to have no sympathy, to use Coriolanus' words, for these "souls of geese / that bear the shape of man" (I. v. 9-10). From a political point of view, it is worth mentioning that Shakespeare in his play, described appropriately by Vickers as "Shakespeare's most detailed analysis of politics," $(1976,7)$ through highlighting the grotesque aspects of Coriolanus especially those related to his language, introduces a tragic protagonist who "does not invite audience identification [and sympathy]" (Hatlen 1997, 393). In a similar way, through degradation and humiliation, there appears no sympathy for the plebeians of Coriolanus. Instead, Shakespeare has intended to provide an abyss between his characters and the audience in order to make his audience stand and criticize a contemporary political issue. Therefore, both because of the created distance and lack of sympathy for the characters, the audiences often see the play "as working not so much upon [their] passions as upon [their] analytic faculties" (393).

\section{CONCLUSIONS}

Though written in the late 1920s, Bakhtin's works became known in Western literary criticism in the late 1960s when post-structuralism was the leading literary theory. Indeed, Bakhtin anticipates such poststructuralist critics as Jacque Derrida since both believed that "language is fundamentally multiple in its meaning." Bakhtin in his works by using the concepts of "carnival," "grotesque body" and "dialogism" rejects traditional Aristotelian logic of either-or which has a monological mode and "demand[s] that a given interpretation of a text be either accepted or rejected" (Booker 1996, 103-5). Instead, he embraces a dialogical concept of truth by which competing interpretations must be considered and chosen by the 
readers. Hence, the most important aspect of Bakhtin's ideas seems to be "ambivalence and its refusal to allow simple choices between opposing alternatives;" (Booker 1996, 105) that is, it permits different alternatives and viewpoints to interact in a dialogic way. This idea is echoed in Coriolanus that according to Kott "could not wholly satisfy either aristocrats, or republicans; the friends of the people, or its enemies" (1967, 142). Regarding the language, also, Bakhtin believes that in a literary work not only there is an opposition or dialogism between high and low languages, but also one's utterance is a "double-accented, double-styled hybrid construction" (1981, 305) with anti-authoritative centrifugal tendencies, since it is mingled with others' words.

Shakespeare as a high-culture figure ignores conventional hierarchy and decorum by attributing some grotesque aspects to his protagonist. The most important characteristic of Coriolanus is his cursing language that changes him into a grotesque figure and undermines his elevated language as well as the unitary and authoritative language of the play as a whole. In this regard, Bakhtin argues that "whenever men laugh and curse [...] their speech is filled with bodily images" that is filled with grotesquerie $(1984,318)$. Similarly, it is grotesque that by putting ugliness and offence into Coriolanus' language, Shakespeare averts the audience's sympathy for this unpopular and forsaken tragic hero. On the other hand, Shakespeare uses the techniques of degradation and humiliation to make his audience have no sympathy for the Roman citizens. Despite the fact that Elizabethan and Jacobean theatres were loyal to Aristotle's ideas regarding tragedy, these conventions were sometimes ignored by Shakespeare in his plays.

In Coriolanus, he rejects Aristotelian dramatic theatre and either-or logic in favor of a Brechtian epic theatre and the logic of neither-nor. In contrast to dramatic theatre in which characters are represented in such a way to stimulate the audience's sympathy, in epic theatre the attempt is to arouse the capacity for taking action and criticizing a problem. Coriolanus is such a tragedy that separates the audience from the characters and makes them sympathize with neither patricians nor plebeians to draw all attentions to the corn issue England faced at the beginning of the seventeenth century. To use Jan Kott's words, Coriolanus is a "modern model of the theatre Brecht called epic theatre than Shakespeare's Histories" $(1967,153)$. Finally, it is worth mentioning that Shakespeare, in Coriolanus, does not follow conventional hierarchies; he gets his protagonist to use an anti-hierarchical, anti-conventional and antiauthoritative language, and seemingly celebrates a Bakhtinian anarchic body of Roman republic. However, he implicitly shows that ignoring hierarchies will lead to perdition as the main reason for Coriolanus' tragedy is his cursing Calibanian language. This shows to what extent a writer can be shaped by the discursive practices of his time.

\section{References}

[1] Bakhtin, M. M. 1981. The Dialogic Imagination. Ed. Michael Holquist. Translated by Caryl Emerson and Michael Holquist. Austin: Texas University Press.

[2] Bakhtin, M. M. 1984. Rabelais and His World. Translated by Helene Iswolsky. Bloomington: Indiana University Press.

[3] Bakhtin, M. M. 1986. Speech Genres and Other Late Essays. Translated by Vern W. McGee. Edited by Caryl Emerson and Michael Holquist. Austin: Texas University Press. 
[4] Benjamin, Walter. 1998. Understanding Brecht. Translated by Anna Bostock. London: Verso.

[5] Booker, M. Keith. 1996. A Practical Introduction to Literary Theory and Criticism. Arkansas: Longman.

[6] Brown, John Russel. 2001. "Coriolanus: Power and Uncertainty". In Shakespeare: The Tragedies. Houndmills and New York: Palgrave, 342-363.

[7] Clemen, W. H. 1951. The Development of Shakespeare's Imagery. New York: A Drama book.

[8] Dentith, Simon. 2005. Bakhtinian Thought: An Introductory Reader. London and New York: Taylor \& Francis e-library.

[9] Eagleton, Terry. 1986. William Shakespeare. Oxford: Blackwell.

[10] Eliot, T. S. 1932. "Hamlet". In Selected Essays. London: Faber and Faber Limited, 141-146.

[11] Farnham, Willard. 1965. "Coriolanus". In Discussions of Shakespeare's Roman Plays. Edited by Maurice Charney. Boston: D. C. Heath and Company, 135-155.

[12] Habib, M. A. R. 2005. A History of Literary Criticism: From Plato to the Present. Oxford: Blackwell Publishing Ltd.

[13] Hatlen, Burton. 1997. "The 'Noble Thing' and the 'Boy of Tears': Coriolanus and the Embarrassment of Identity". English Literary Renaissance. 27(3): 393-420.

[14] Holquist, Michael. 1977. Dostoevsky and the Novel. Princeton: Princeton University Press.

[15] Hunt, Maurice. 2004. "The Backward Voice of Coriol-anus". Shakespeare Studies. ProQuest Research Library, 220-239. http://www.proQuest.umi.com.

[16] Jorgensen, Paul A. 1965. "The Soldier in Society: From Casque to Cushion". In Discussions of Shakespeare's Roman Plays. Edited by Maurice Charney. Boston: D. C. Heath and Company, 121-130.

[17] Kott, Jan. 1967. "Coriolanus or Shakespearian Contradictions". In Shakespeare Our Contemporary. London: Methuen and Co Ltd, 141-167.

[18] Langis, Unhae. 2010. "Coriolanus: Inordinate Passions and Powers in Personal and Political Goverance". Comparative Drama. 44(1): ProQuest Research Library, 1-27.

[19] Meyerhold, Vsevolod. 1969. "The Fairground Booth". In Meyerhold on Theatre. Translated by Edward Braun. London: Eyre Methuen.

[20] Parker, R. B, ed. 1998. The Tragedy of Coriolanus. Oxford: Oxford University Press.

[21] Shakespeare, William. 1998. Coriolanus: The Oxford Shakespeare. Edited by R. B. Parker. Oxford: Oxford University Press.

[22] Shakespeare, William. 2009. The Tempest: The Cambridge Dover Wilson Shakespeare. Edited by John Dover Wilson. Cambridge: Cambridge University Press.

[23] Sicherman, Carol. 1972. "Coriolanus: The Failure of Words". The John Hopkins University Press. 39(2): 189-207. 
[24] Stallybrass, Peter and Allen White. 1986. The Politics and Poetics of Transgression. Ithaca, N. Y.: Cornel University Press.

[25] Van Dijk, Maarten. 2001. "Lice in Fur: the aesthetics of cheek and Shakespearean production strategy". In Shakespeare and Modern Theatre. Edited by Michael Bristol \& Kathleen McLuskie. London: Routledge, 160-180.

[26] Vickers, Brian, ed. 1976. "Shakespeare: Coriolanus". Studies in English Literature. London: 1(58): 1-63. 